Dialectologia 16 (2016), 1-18.

ISSN: 2013-2247

Received 27 August 2014.

Accepted 29 December 2014.

\title{
LANGUAGE CHANGE IN A POST-CREOLE CONTACT SETTING: NON-STANDARD AIN'T NEGATION IN SUFFOLK
}

\author{
Michelle BRAÑA-STRAW \\ University of Gloucestershire* \\ mstraw@glos.ac.uk
}

\begin{abstract}
This paper describes preliminary research on the role ain't for two groups of British speakers living in Suffolk: Anglos and Barbadians. The issues addressed are of relevance to sociolinguists and creolists. In most Anglophone countries, including Britain, the functions of ain't are remarkably similar - occurring with present tense verbs be and have only. An Anglophone pattern, based on previously reported tendencies and hierarchies is proposed and is used as the basis for comparison. Bajan ${ }^{1}$ is one of the less often studied creoles and absent from work discussing their typological status in relation to L1s. Preliminary results provide some evidence of creole forms among first generation Bajans. Ethnically-aligned contrasts are also found for each generation as Bajans adopt the Anglophone pattern. The paper concludes that any interpretation of social and linguistic factors needs to be supplemented by further interactional analysis to account for the considerable inter-individual variation.
\end{abstract}

\section{Keywords}

syntactic variation, non-standard negation, British English, Barbadian English, Creoles

\footnotetext{
* Dept of Humanities. Swindon Road. Cheltenham. Gloucestershire, UK.

${ }^{1}$ Henceforth, I refer to the speakers of Barbadian heritage and the non-standard forms spoken in Barbados as 'Bajan'. This is a term used by Barbadians, in Barbados and in Britain, to refer to themselves and their language.
} 


\section{CAMBIO LINGÜÍSTICO EN UN ENTORNO DE CONTACTO POSTCRIOLLO:}

\section{LA NEGACIÓN NO ESTÁNDAR AIN’T EN SUFFOLK}

\section{Resumen}

Este trabajo describe la investigación preliminar sobre el papel de ain't en dos grupos de hablantes británicos que viven en Suffolk: anglos y barbadenses. Los temas tratados son de interés para los sociolingüistas y criollistas. En la mayoría de los países de habla inglesa, incluyendo Gran Bretaña, las funciones de ain't son notablemente similares - ocurre sólo con los verbos ser y tener en presente de indicativo. Se propone un patrón anglófono, basado en tendencias y jerarquías indicadas anteriormente, que se utiliza como base para la comparación. Bajan es uno de los criollos estudiados con menos frecuencia y está ausente de trabajos que cuestionen su tipología en relación con la L1. Los resultados preliminares proporcionan alguna evidencia de formas criollas entre la primera generación de Bajans. Los contrastes étnicamente alineados también se encuentran en cada generación cuando los Bajans adoptan el patrón de habla inglesa. El artículo concluye que cualquier interpretación de factores sociales y lingüísticos necesita ser complementado con un posterior análisis interaccional para dar cuenta de la considerable variación interindividual que existe.

\section{Palabras clave}

variación sintáctica, negación no estándar, inglés británico, inglés de Barbados, criollos²

\section{Introduction}

This paper reports on preliminary research on a well-know dialect feature, ain't. It is one of a number of features, which tends to recur in varieties of English. Szmrecsanyi \& Kortmann's (2009) survey of 76 features across 46 English varieties, found that L1 varieties are distinct from creoles, with L2 falling somewhere in between the two. They suggest a number of implicational tendencies based on highly significant patterns across the varieties. Neither Suffolk, nor Bajan are included in the survey. However, Suffolk resides in the larger region of East Anglia, which is one of the British regions included in the survey and which conforms to the implicational tendencies.

The main tendency identified ain't - a variety of English will either have ain't for be and have, or it will have neither. We can further refine the tendency for L1 varieties, which I call the Anglophone pattern. This pattern is widely attested and occurs in the

\footnotetext{
${ }^{2}$ De ahora en adelante, me refiero a los hablantes patrimoniales de Barbados y las formas no estándar que se hablan en Barbados como "Bajan". Este es un término utilizado por los barbadenses, en Barbados y en Gran Bretaña, para referirse a sí mismos y a su idioma.
} 
present tense of be and have only. Furthermore, it is restricted to the aux have but cannot occur with have as a main verb.

1. Present tense aux be (e.g. You ain't talking to me)

2. Present tense cop be (e.g. He ain't taller than my brother)

3. Present tense aux have (e.g. We ain't seen his friend)

4. *Present tense have main verb (e.g. *I ain't have sugar with my tea)

Kortmann \& Szmrecsanyi (2004: 1147-1153) report that ain't occurring with a main verb as in example 4 is one of the rarest of the 76 features surveyed; present in only 7 of the 46 varieties, including two creoles: Gullah and Trinidadian/Toboganian Creole. A number of scholars have suggested that ain't acts as a general negator in Anglophone creoles (example 5), occurring in a wider range of contexts than L1 varieties.

5. ain't as generic negator before a main verb (e.g. I ain't know him)

The site for this research is the post-creole, contact setting, in the town of Ipswich, Suffolk. The speakers in this study comprise Barbadian immigrants, their descendants and Anglos. The Suffolk data allows us firstly to compare speakers from L1 and creole backgrounds to gauge the extent that they are typologically distinctive. We can expect that Anglos would conform to the Anglophone Pattern described above, given that Suffolk lies in East Anglia. Neither Bajan, nor related Eastern Caribbean creoles are included in the survey. However, a number of Caribbean scholars consider ain't to be a general negator in Bajan.

This leads to our first research question: how typologically distinctive are Suffolk English and Bajan? In order to answer this question, I compare old Anglos with $1^{\text {st }}$ gen. Bajans to see whether:

1.a) Suffolk Anglos and Bajans conform to the Anglophone Pattern?

1.b) Bajans have any evidence of a general negator ain't?

The work of Anderwald (2002) is relevant in helping to determine further tendencies of the Anglophone pattern. Her study is based on the British National Corpus of spoken English (BNC). She concludes that ain't has undergone a process of regularisation, with infrequent contexts producing higher frequencies of ain't than 
higher frequency environments which tend to retain more complexity. The highest frequency environment is cop be followed by aux have and then aux be.

\begin{tabular}{|l|l|l|l|}
\hline \multicolumn{1}{|c|}{ Idealised } & \multicolumn{1}{c|}{ aux be } & \multicolumn{1}{c|}{$>$ aux have } & \multicolumn{1}{c|}{ cop be } \\
\hline BNC corpus average & aux have $14.1 \%$ & aux be $13.3 \%$ & cop be $7.6 \%$ \\
\hline East Anglia region & aux have 31.3\% & aux be $17.3 \%$ & cop be $8.2 \%$ \\
\hline Reading, South West & aux have & cop be & aux be \\
\hline
\end{tabular}

(Anderwald 2002; Cheshire 1982)

Table 1. Anglophone Pattern frequency hierarchy of Ain' $^{3}$

Table 1 is based on Anderwald's BNC corpus research. She describes an idealised pattern based on absolute frequencies of occurrence of verbs be and have, in the corpus; the BNC average across all British regions surveyed; and the figures for East Anglia (EA). I also include the hierarchical order reported by Cheshire (1982) for Reading in the South West. The table shows clearly a common tendency for ain't to occur more frequently with have than be. This tendency can therefore be included in the Anglophone pattern, at least as it occurs for British English ( $\mathrm{BrE})$. The figures included for the BNC average and EA are included here as relevant points of comparison with the Suffolk data. EA has higher rates of ain't with have, than the BNC average.

This leads to our second question: to what extent do Suffolk speakers conform to the Anglophone pattern found in the BNC data and EA region, in particular?

Ain't comprises a number of variants that may be linguistically and socially conditioned. Kortmann \& Szmrecsanyi (2004: 1147) highlight one notable example the invariant form innit as in example 6, which occurs only in tag questions

6. invariant non-concord tags (They had them in their hair, innit?)

This feature has been observed in British varieties of English, especially in London and the South East, but not in Caribbean Creoles (see for example, Stenstrom 1997 and Torgersen \& Gabrielatos 2009). Gunnel \& Hoffman (2006: 283, 286) compares the BNC to an American corpus and finds that whilst tag questions occur in both varieties, they were nine times more frequent in the British data. She also observes the invariant form innit does not occur in American English. Innit seems to be exclusively British.

\footnotetext{
${ }^{3}$ Aux refers to Auxiliary, Cop refers to Copula.
} 
This leads to our third question:

3.a) What are the range of variants for ain't in the Suffolk data?

3.b) What linguistic and social factors condition the variation?

\section{The Data and Methodology}

The Suffolk data consists of sociolinguistic interviews from 24 speakers supplemented by ethnographic participant and non-participant observations over a three year period, between 2000 and 2003. The data are a sub-sample from a larger dataset of 74 speakers comprising, Anglos, and Caribbeans from a range of islands including, Jamaica, Barbados, Antigua, Nevis, St Vincent. The largest two groups are from Jamaica and Barbados. This paper reports preliminary findings for Anglos and Barbadians only. Speakers are grouped according to life-stages, old - retired or nearing retirement, mid - established in work and with families and, young - mostly secondary school children. These life stages also coincide with the settlement patterns of the Barbadians. The first generation ${ }^{4}$ of Barbadians came to England as adults in the 1950 s and 1960s and are over 60 years old. The second generation arrived in the 1970s age 10 or are British born. This group is in the mid-age category. The third generation are all British born and are in the young category. The results are grouped by ethnicity and age. I also provide a qualitative account of other social factors where relevant.

A total of 809 tokens are analysed split between be and have. Tokens of be are three times more frequently occurring than have. A further breakdown in verb be will not considered at this point. Rather I compare the data against the main tendency shown in Table 1, i.e. that ain't occurs more often with have than be.

For the purposes of comparison with findings from the BNC, the linguistic environment is coded for non-tags and tags. The dependent variable is coded as ain't, negative contraction, auxiliary contraction and full negation. The main forms of ain't are further coded (ain't, in't and innit). Initial indications, are that innit, may not be completely invariant. For example, Anderwald (2002: 147) suggests that it is semi-

\footnotetext{
${ }^{4}$ Henceforth, I refer to the generations as $1^{\text {st }}$ gen., $2^{\text {nd }}$ gen. and $3^{\text {rd }}$ gen.
} 
invariant. In the first instance, I shall include innit in the overall figures and then focus in more detail on its distribution. Innit is considered to be a peculiarly British feature, but tends to be excluded from larger studies (Gunnel \& Hoffmann 2006). This smaller study provides the opportunity to examine how this form behaves in two ethnic groups.

The descriptions of Bajan have either emphasised its similarities with British English or its typological distinctiveness, as a creole. Others, such as Walker \& Sidnell (2011) consider the possibility of co-existent systems rather than a single highly variable system along classic continuum model proposed by (e.g. Bickerton 1975; DeCamp 1971). A variationist approach does not have to make judgments of this kind. As well as presence-absence of a feature, variationists look at relative frequencies and consider linguistic or social determinants. A variationist approach is used here, because Bajan has the longest sustained links with British English and, because the Bajans in this study are assimilating to a local form of British English. This kind of complex situation where contact occurs at several stages of development requires a more open approach. Initial empirical results allow us to identify the main patterns of variation across the data. This is supplemented by qualitative observations with a view to establishing the best way to interpret the data.

\section{Bajan negation}

I now summarise the literature on Bajan negation before presenting my analysis of the Suffolk data. Van Herk (2003: 243) observes that descriptions of Bajan tend to assume that all non-standard features are creole forms. Ain't in particular, is considered to be part of a creole grammar, perhaps a mesolectal feature, rather than dialectal feature of English. Walker \& Sidnell (2011) conducted a variationist study of Bequia, an Eastern Caribbean variety, historically related to Bajan. They found different patterns of Creole and English forms linked to historical and geographical settlement patterns on the island. As well as differences in terms of presence/absence of features, the cooccurrence of other non-standard features, e.g. negative concord, $\mathrm{TMA}^{5} \mathrm{~s}$ are also relevant. The authors interpret different rates of occurrence and linguistic conditioning,

\footnotetext{
${ }^{5}$ TMA - tense, mood and aspect markers.
} 
as being due to the same underlying system, with subsequent restructuring for some communities. Their discussion avoids the need to classify features in terms of varying degrees of creole.

A number of scholars provide examples to show that in Bajan, ain't can occur across a wider range of verb and tense contexts than L1 English varieties. Ain't may be functioning like the preverbal no. Burrowes (1983) is one of a number of scholars who considers ain't to be part of a creole grammar. She identifies Anglophone Creoles as having the following forms as a negator $-n o, n$, in and that Barbados has related variants in, din and ain't. (see Kortmann \& Szmrecsanyi 2004; Szmrecsanyi \& Kortmann 2009: 1646, for a review of the main differences between creoles and L1 varieties). In example 11 ain't occurs before a verb phrase in Bajan:

11. Uh ain't did stan fo lie much - I didn't stand to lie much (Burrowes 1983: 43).

The form din is derived from didn't but with a different distribution/function in English-Based Creoles from British English (Meyerhoff \& Walker 2012: 217-8; Walker \& Sidnell 2011: 3). Din is also found in Barbadian Creole. Van Herk (2003: 255) describes the system of an elderly Bajan lady. She represents the most basilectal speaker in his sample. Her use of ain't covers a much wider range of contexts than in BrE including where BrE would use do in present and past tense and be in past tense. The following examples indicate a number of functions for ain't and din that are not found in BrE.

The past tense of be (wasn't) can be replaced with either ain't or din, as in:

12. I din born big or I ain't born big - wasn't (Van Herk 2003: 254)

The verb do present tense, can be replaced with ain't as in:

13. It ain't concern you - It doesn't concern you (Van Herk 2003: 254).

Rickford \& Handler suggest that a related form (y)ent is a mesolectal feature derived from ain't that can occur with do past as in:

14. I yent say nothing to she? - I didn't say... (c 1800s: Rickford \& Handler 1994: 242-3). 


\section{Results}

I present examples of the linguistic environment for ain't for $1^{\text {st }}$ gen. Bajans. Examples 15 and 16 indicate that ain't is typologically distinctive. It occurs with a greater number of verbs and tenses than BrE. There is some evidence to suggest that ain't covaries with the Barbadian contraction din mostly for the verb do, and for past tense be.

15. Ain't/din with verbs do past

a) dey pick me for one dat I ain't had a cat in hell of wining [274Buster] - didn't have

b) we ain't get de treatment [86Bessy] - didn't get

c) I din know a lot of people [93Betty]-didn't know

16. Ain't/din with can, be past,

a) I think you can go on the back, ain't you mm [230Bessy] - can't you

b) she couldn't let me in because her husband ain't der [124Bessy] wasn't there

c) we were black ain't we [92Bessy] - weren't we

d) I din so acquainted with [294Betty] - I wasn't so acquainted with

The examples occur mostly in Bessy's speech and to a lesser extent, Betty, even though the latter is the most basilectal speaker. $1^{\text {st }}$ gen. males use the most acrolectal speech. Buster uses the Bajan din for didn't and in 15a) ain't is used with the lexical verb have, that is blocked in the Anglophone pattern. The apparent gender distinction can be explained to an extent by social factors. The men came from the main city of Bridgetown and had wider social networks. The women came from rural communities and their social networks were confined to family and close contacts. In addition, Berty had some post-16 privately-paid, education. Scholars working on Eastern Caribbean varieties have noted that geographical settlements can account for such linguistic differences. In particular, the rural/urban distinction is an important social factor as to whether an individual uses basilectal features. Whilst the differences between $1^{\text {st }}$ gen. men and women can be explained by the differences in social networks afforded by the urban/rural environments, it is not the whole picture. Betty has the most basilectal features in her speech including copula deletion, non marking of the past tense (Braña- 
Straw 2011: 66). She grew up in the rural environment in the parish of St John. Bessy grew up in the less rural parish of Christchurch and had more frequent access to the urban centre, having spent time in Bridgetown working for a family friend. We might expect that Betty would be the most frequent user of basilectal forms of ain't. Individual factors seem to be at play and will be addressed in the discussion.

I now turn to the empirical results for ain't with verbs be and have in the present tense. This allows us to determine the extent that each group conforms to the Anglophone pattern and to compare both frequency of occurrence of ain't and its main variants with the BNC data (as per Anderwald 2002).

\begin{tabular}{l|l|l|l|l|l} 
Groups & Verb & Aux & & Neg (ex. ain't) & (inc. ain't) \\
\hline \multirow{2}{*}{ Bajans } & be & $\mathbf{5 8 . 3 3}$ & $>$ & 21.83 & 34.52 \\
\cline { 2 - 6 } & have & 6.6 & $<$ & 80.19 & $\mathbf{9 2 . 4 5}$ \\
\hline \multirow{2}{*}{ Anglos } & be & 46.82 & $<=$ & 31.53 & $\mathbf{4 8 . 0 9}$ \\
\cline { 2 - 6 } & have & 5.88 & $<$ & 77.94 & $\mathbf{9 2 . 4 5}$
\end{tabular}

Table 2. Anglophone Hierarchy for be and have, present tense (\%)

Table 2 shows the frequencies of aux versus neg. The expected hierarchy is aux $>$ neg for be and aux < neg have. The hierarchy certainly holds for Bajans, but is not so clear cut for the Anglos who have similar rates of aux and neg for be. In addition, overall rates of aux for be are comparatively low (58\% Bajans, $47 \%$ Anglos) compared to the BNC data (80\% EA, 92\% BNC average). The neg rates for have are in line with EA (97\%) if we include ain't, (Bajans and Anglos 92\%).

\begin{tabular}{l|c|l|l} 
Group & be & & have \\
\hline Bajans & 12.70 & $=$ & 12.26 \\
\hline Anglos & 16.56 & $>$ & 13.24 \\
\hline BNC & 8.90 & $<$ & 14.10 \\
\hline EA $^{6}$ & 10.50 & $<$ & 31.30
\end{tabular}

Table 3. Frequency of ain't for the Anglophone pattern (\%)

Table 3 compares the relative frequencies of ain't in the Suffolk and BNC data. Suffolk Anglos have the highest rates of ain't for be, followed by Bajans, then EA. For have, $\mathrm{EA}$ has higher rates than the $\mathrm{BNC}$ average, whereas rates for Anglos and Bajans

\footnotetext{
${ }^{6}$ East Anglia region.
} 
are slightly lower than the BNC average. A noticeable difference is that ain't occurs more frequently with have than be in the BNC data. The reverse pattern is found for Suffolk Anglos, whilst there is no difference in rates for Bajans. This result is likely to be due to the decision to include innit forms, rather than to any inherent differences.

\begin{tabular}{l|l|l|l|l} 
Group & Verb & Non-Tags & & Tags \\
\hline BNC & be & 5.8 & $<$ & 14.8 \\
\hline BNC & have & 12.9 & $<$ & 18.2 \\
\hline Anglos & be & 3.9 & $<$ & $\mathbf{3 5 . 2}$ \\
\hline Anglos & have & 13.6 & $>$ & $\mathbf{1 2}$ \\
\hline Bajans & be & 4.15 & $<$ & $\mathbf{3 7 . 2 3}$ \\
\hline Bajans & have & 10.3 & $<$ & 17.4 \\
Table 4. Percentage Frequency of ain't non-tags v tags
\end{tabular}

Table 4 compares the frequency of ain't in non-tags and tags. Bajans follow the BNC pattern, in which ain't occurs more frequently in tags than non-tags for both verbs. Anglos have the same pattern for be but not for have. Both groups have substantially higher rates of occurrence than in the BNC data with verb be. This is largely due to inclusion of innit. However, the decision to include innit does not affect the overall patterns found in the data.

\begin{tabular}{l|l|l|l} 
Group & Form & Non-tags & tags \\
\hline Anglos & in't & 70 & $<10$ \\
\hline & innit & Nil & $>60$ \\
\hline & ain't & 30 & 30 \\
\hline Bajans & in't & 10 & $<10$ \\
\hline & Innit & Nil & $>75$ \\
\hline & Ain't & 90 & 15
\end{tabular}

Table 5a. Forms of ain't occurring with verb be (\%)

\begin{tabular}{l|l|l|l} 
Group & Form & Non-tags & tags \\
\hline Anglos & in't & Nil & nil \\
\hline & innit & Nil & nil \\
\hline & ain't & 100 & 100 \\
\hline Bajans & in't & nil & 20 \\
\hline & innit & nil & 40 \\
\hline & ain't & $>85$ & 40 \\
\hline & han't & $<15$ & nil
\end{tabular}

Table 5b. Forms of ain't occurring with verb have in percentages 
Tables $5 a$ and $5 b$ show the distribution of the main variants of ain't. According to Anderwald (2002: 130) in't does not occur at all with be in EA. The Suffolk data provides evidence to the contrary. Anglos have $i^{\prime} t$ as the main form in non-tags at $70 \%$ compared with only $13.3 \%$ BNC average. By contrast in tags, in't is the least frequent form at less than $10 \%$ compared with the BNC average of $65.9 \%$. Bajans also have the in't form in tags at $20 \%$. The percentages are probably not directly comparable due to my inclusion of innit. However, the main point holds, that the Suffolk data contradict Anderwald's claim that in't is not used in East Anglia. Now to compare Anglos with Bajans, the main difference is in non-tags. The main form for Anglos is in't, whereas the main form for Bajans is ain't. If we look at tags, we can see that the main form is innit for both groups and that they have a similar distribution of forms innit>ain't>in't.

Table $5 b$ charts the distribution of forms between non-tags and tags with verb have. For both groups, the form ain't occurs categorically in non-tags ${ }^{7}$. Anglos also have categorical use of ain't in tags, whereas Bajans have a fairly even distribution between the forms ain't, innit and in't. Whilst, innit is restricted to tags for both groups, the figures indicate that Bajans are using innit in a greater number of linguistic environments than simply as an alternative form of isn't it, as their Anglo counterparts do. Further examination of the data reveals that it is Bajan-born speakers from the $1^{\text {st }}$ and $2^{\text {nd }}$ gen. who use innit in this way. British-born speakers do not, rather they use the Anglo pattern, if at all ${ }^{8}$. Example 17 provides examples of the different ways in which the two ethnic groups use innit. For the Anglos, innit can only replace isn't it.

17. Innit

a) Oh right, yeah that's nice, innit? And you can see all of the bird life, all the waders and that sort of thing (Sadie, mid-age Anglo)

b) Life is like that, innit? (Simon, old Anglo)

c) It's a sanctuary for them, to retreat from London, you have to come up here, innit? (Bernard, $2^{\text {nd }}$ gen. Bajan)

d) I thought to myself the word type don't seem write there, innit? (Bessy $1^{\text {st }}$ gen. Bajan)

\footnotetext{
${ }^{7}$ Given the small number of token numbers we can consider Bajan results to be categorical. There was only one instance of another form han't by Bernard.

${ }^{8}$ Many speakers in the sample use only standard forms.
} 


\section{Summary and Discussion}

This results show that Suffolk Bajans ( $2^{\text {nd }}$ and $3^{\text {rd }}$ gen.) and Anglos mostly conform to the Anglophone pattern defined by the main tendency and frequency hierarchy proposed in the literature. The constraints for the Anglophone pattern are that ain't only occurs with verbs be (cop and aux) and have (aux), in the present tense. It cannot occur with have as a main verb. Furthermore, ain't occurs more frequently with have than be. A comparison with the BNC data and the regional figures for East Anglia have shown that the Suffolk data has similar patterns in terms of the hierarchy of usage between standard and non-standard variants.

The post-creole contact situation in Suffolk has thrown up a number of ethnically distinctive patterns in terms of the distribution of variant forms of ain't and the linguistic conditioning. Below is a summary of the main distinctions to be found between Bajans and Anglos. ${ }^{9}$

1. Anglos favour in't with be (non-tags) and ain't is categorical for have

2. Bajans favour ain't with be (non-tags) and variable forms for have

3. $1^{\text {st }}$ gen. Bajans use of ain't is not restricted to the Anglophone pattern

4. $1^{\text {st }} / 2^{\text {nd }}$ gen. Bajan-born speakers use the invariant innit form in tags, whereas Anglos only use it in place of isn't it, in tags.

There is considerable inter-speaker variation within the data. Many speakers have produced exclusively standard forms, whilst others are frequent users of non-standard forms. Analysing syntactic variation is problematic if treated purely from a quantitative perspective. Cheshire (2005) shows that qualitative analysis is useful to add further insights, especially in the context of tag questions and formulaic expressions. The remainder of the discussion will focus on the results 3 . and 4. above, and highlight further areas for research.

Innit is increasingly used in tags and has multiple discourse functions (Cheshire 1982, 1991, 2005). Neither tags, nor innit are described in the linguistic literature for Bajan. The invariant form occurs with be and have across the person/number paradigm

\footnotetext{
${ }^{9}$ There are a number of other distinctions in the data that occur in each generation but these will be discussed in future work.
} 
in the speech of $1^{\text {st }}$ and $2^{\text {nd }}$ gen. immigrants indicating that it could be an innovation. Bajans may have acquired both the form and the tag environment in Britain. The invariant form could have arisen independently from acquisition strategies based on overgeneralization, i.e. the extension of a linguistic form to a greater number of linguistic environments, and/or it could perform a range of discourse functions. On the other hand, Anglos use innit exclusively to replace isn't it in tags. Bajans could have extended the linguistic environment to include all person/number forms of be and have. Earlier research has shown that this strategy is used for other variables. For example, Edward, a $2^{\text {nd }}$ gen. speaker was found to extend the use of glottalised forms of $/ t /$ to environments that were blocked for Anglo speakers (Braña-Straw 2007: 16-17). Studies on the ethnically diverse population of London, suggest that ethnic minorities are the greatest users of tags and the invariant form innit (Palacios-Martínez 2010; Torgersen \& Gabrielatos 2009). These earlier studies agree that innit as an invariant form is an innovation, led by young non-Anglo males in inner London. My findings seems to support the claim that invariant innit is an ethnically driven innovation. It also provides further evidence that the feature may have been present much earlier in immigrant speech, occurring as it does in the speech of Bajans who arrived in the 1960s. In Suffolk, invariant innit may be perceived as immigrant speech, an innovation that is not taken up by British born $3^{\text {rd }}$ gen. Bajans and not present in Anglo speakers.

I stated earlier that the Suffolk data mostly conforms to the Anglophone pattern. However, $1^{\text {st }}$ gen. Bajans provide us with evidence of a creolised system. Ain't can occur with be and have in the past tense, with have as a main verb and with other TMAs, particularly do. The data seem to point to ain't as a generic negator as claimed by creole scholars. Even with this small sample, there is considerable variation between individuals. The use of creole features could be attributable to sociolinguistic factors that have been transferred from the island situation. In this study, the female speakers exhibit most of the creole features. I include a summary of the main features of $1^{\text {st }}$ gen. Bajan island background. These are some of the factors that are known to account for variation on Barbados (as described by Le Page \& Tabouret-Keller 1985: 48-49; Van Herk 2003).

1. Berty post secondary, private education, urban, politically active, coloured 
2. Buster secondary education, urban, politically active, black

3. Bessy secondary education, near urban, family networks, black

4. Betty secondary education, remote rural, family networks, self disclosed as poor, black

Pre-migration, the social networks for the women were constructed around family and domestic activities. They had a rural upbringing with relatively more geographical isolation, lower levels of education and income. By contrast, the men's networks were open and multiplex. An interesting component of their networks came from their political activities. Earlier research discussed in Braña-Straw (2011), has shown that political activism continues to be an important factor in Britain, with both men continuing to be politically active in local Anglo-dominated politics. The women's social networks are largely confined to the West Indian community. (Further discussion of the speakers' social situations, pre- and post-migration, are described in Braña-Straw 2011: 64-67.) Based on the social factors outlined, we can expect Berty to be the most acrolectal speaker and Betty to be the most basilectal speaker. Variationist studies often find that the highest frequency of non-standard features is found in the most vernacular speech. The above social factors would suggest that Betty should be the most vernacular speaker. However, looking at the data, Bessy (not Betty) uses ain't in the greatest number of non-standard environments.

Given that token numbers are too small to support further quantitative analysis, I chart speakers' use of forms, both standard and non-standard in terms of presence or absence. I define the acrolect as consisting of the use of aux and neg contractions for be and have in the present tense. The Anglophone forms consist of ain't and its variants also occurring with be and have in the present tense. The Bajan form is the use of din as a contraction of didn't. The creole forms consist of ain't or din occurring with the main verb have, be and have in the past tense, and other verbs.

\begin{tabular}{|l|l|l|l|l|}
\hline Speaker & Standard/Acrolect & Anglophone & Bajan/Mesolect & Creole/Basilect \\
\hline Berty & Yes & No & No & No \\
\hline Buster & Yes & No & Yes & Yes \\
\hline Bessy & Yes & Yes & Yes & Yes \\
\hline Betty & Yes & Yes & Yes & Yes \\
\hline
\end{tabular}

Table 6. Features present in individual speaker sample for $1^{\text {st }}$ gen. Bajans 
Berty as expected is the most acrolectal speaker; he uses standard forms, exclusively. Furthermore, he seems to have a more restrictive pattern than that permitted by the Bristish Standard pattern. Aux contraction is confined to be and neg contraction to have. Buster also has the same restrictions as Berty. This restricted pattern may represent a Bajan acrolect, rather then a British standard. Buster also has some non-standard forms: the Bajan use of din as a further contraction of didn't; and just one token of ain't with the main verb have. As well as social factors, a number of studies suggest that interactional factors play a role in the use of non-standard forms. For example, Palacios-Martínez (2010: 22) investigated the Corpus of London Teenagers for the use of non-standard negation. The corpus includes descendants of West Indian immigrants. She finds that ain't has several pragmatic functions. Speakers might styleshift to non-standard forms for a number of interactional purposes: to denote refusal or opposition or to insist on the point in question. The non-standard forms might appear in narratives, personal anecdotes, stories, jokes. Its function is to make the speech event more lively and realistic or to voice the words of a character. The non-standard was also subject to style-shifting towards the interlocutor. Buster's single use of ain't with the main verb have, occurs in an idiomatic expression I ain't had a cat in hell, at the end of a narrative. It has been suggested that British West Indians are more likely to code-switch between acrolectal and basilectal forms as an act of identity (Le Page \& Tabouret-Keller 1985; Sebba 1993). Further qualitative research is planned to examine pragmatic and interactional functions of these basilectal forms.

Now, we turn to the $1^{\text {st }}$ gen. Bajan females. Social factors suggest that Bessy should be next on the continuum. While token numbers are too few for quantitative analysis at the level of the individual, the few standard tokens produced by Bessy suggests that she has the same restricted acrolect pattern as the males. She uses ain't with be present and past tense, with can present tense and, co-occuring with din to replace didn't. Betty hardly uses standard forms at all. She has one neg token with be and have. Betty uses ain't with be and have in present tense but does not with other TMAs; effectively she displays the Anglophone pattern. Din is used for be past tense and in place of didn't. Again further research is needed to look at possible interactional factors to account for the use of creole features in the females' speech. 
The degree to which $1^{\text {st }}$ gen. Bajans use features from the acrolect varies considerably, as does the degree to which they use mesolectal or basilectal forms. For example, neither male uses the Anglophone pattern whereas the females do. This apparent gender distinction may be due to the differences in social networks both before and after migration. Whilst I have been able to find useful patterns from preliminary quantitative analysis, it is clear that more qualitative research is needed to account further for the patterns observed.

\section{Conclusion}

This study has found that $1^{\text {st }}$ gen. Bajans exhibit patterns that suggest a creole negation system was present in Barbados. The group comparisons are useful to understand how the Suffolk data compares with the BNC. Both Anglos and Bajans conform to the main tendencies of the Anglophone pattern and at first glance it would seem that Bajans are a closer match to the BNC data, than Anglos. Preliminary figures have indicated a number of ethnically-aligned contrasts that are present in all three generations. However, the group figures conceal considerable individual variation. Initial qualitative observations suggest that pre- and post-migration social factors can account for some of the inter-speaker variation for $1^{\text {st }}$ gen. speakers. In addition, a number of interactional factors have been noted in the literature as well as observed in the Suffolk data. More qualitative research will need to focus on the role of interactional factors.

\section{References}

ANDERWALD, Lieselotte (2002) Negation in non-standard British English: Gaps, Regularizations, Asymmetries, London: Routledge.

BICKERTON, Derek (1975) Dynamics of a Creole System, Cambridge: CUP.

BraÑA-StRAW, Michelle (2007) "Maintenance or assimilation? Phonological variation and change in the realization of $/ \mathrm{t} /$ by British Barbadians", in M. Huber \& V. Velupillai (eds.), 
Dialectologia 16 (2016), 1-18.

ISSN: 2013-2247

Synchronic and Diachronic Perspectives on Contact Languages, Amsterdam: John Benjamins, 3-22.

BRAÑA-STRAW, Michelle (2011) "Putting individuals back in contact: accommodation strategies by Barbadians in Ipswich", in L. Hinrichs \& J. Farquharson (eds.), Variation in the Caribbean: From creole continua to individual agency, Amsterdam: Benjamins, 57-78.

BURROWES, Audrey (in collaboration with Richard Allsopp) (1983) "Barbadian Creole: A note on its social history and structure", in L. Carrington, D. Craig \& R. Todd Dandaré (eds.), Studies in Caribbean Language, St. Augustine, Trinidad: Society for Caribbean Linguistics, 38-45.

CHESHIRE, Jenny (1982) Variation in an English Dialect: A Sociolinguistic Study, Cambridge: Cambridge University Press.

CHESHIRE, Jenny (1991) "Variation in the use of ain't in an urban British English dialect. In Dialects of English: Studies in grammatical variation", in P. Trudgill \& J. K. Chambers (eds.), Singapore: Longman Singapore Publishers, 54-73.

CHESHIRE, Jenny (2005) "Syntactic Variation and beyond: Gender and Social Class Variation in the Use of Discourse-New markers", Journal of Sociolinguistics, 9, 4, 479-508.

DECAMP, David (1971) "Toward a generative analysis of a post-creole speech continuum", in D. Hymes (ed.), Pidginization and Creolisation of Languages, Cambridge: Cambridge University Press, 349-370.

GunNel, Tottie \& Sebastian HoffManN (2006) "Tag Questions in British and American English", Journal of English Linguistics, 34, 4, 283-311.

KORTMANN, Bernd \& Benedikt SZMRECSANYI (2004) “Global synopsis: morphological and syntactic variation in English", A handbook of varieties of English, vol. 2, Berlin/New York: Mouton de Gruyter, 1142-1202.

LE PAGE, Robert Brock \& Andrée TABOURET-KelleR (1985) Acts of Identity: Creole-Based Approaches to Language and Ethnicity, Cambridge: Cambridge University Press.

MeYerhoff, Miriam \& James A. WALKer (2012) "Grammatical Variation in Bequia (St Vincent and the Grenadines)", Journal of Pidgin and Creole Languages, 27, 2, 209-234.

Palacios-Martínez, Ignacio M. (2010) “'It Ain't Nothing to Do with My School.' Variation and Pragmatic Uses of Ain't in the Language of British English Teenagers", English Studies, 91, 5, 548-566.

RICKFORD, John R. \& Jerome S. HANDLER (1994) "Textual Evidence on the Nature of Early Barbadian Speech, 1676-1835", Journal of Pidgin and Creole Languages, 9, 2, 221-55. 
SEBBA, Mark (1993) London Jamaican: Language Systems in Interaction, London: Longman.

Stenstrom, Anna-B. (1997) "Tags in teenage talk", in U. Fries, V. Müller \& P. Schneider (eds.), From AElfric to the New York Times. Studies in English Corpus Linguistics, Amsterdam: Rodopi, 139-147.

SZMRECSANYI, Benedikt \& Bernd KoRTMANN (2009) "Vernacular universals and angloversals in a typological perspective", in F. Markku, J. Klemola \& H. Paulasto (eds.), Vernacular universals and language contacts: Evidence from varieties of English and beyond, New York: Taylor \& Francis, 33-53.

Torgersen, Eivind \& Costas Gabrielatos (2009) "A Corpus-Based Study of Invariant Tags in London English", Paper presented at Corpus Linguistics 2009, 22-25 July 2009, University of Liverpool.

VAN HeRK, Gerard (2003) "Barbadian lects: Beyond meso", in M. Aceto \& J. P. Williams (eds.), Contact Englishes of the Eastern Caribbean, Amsterdam: John Benjamins, 241-264.

WALKER, James \& Jack SIDNELL (2011) "Inherent Variability and Coexistent Systems: Negation on Bequia", in L. Hinrichs \& J. Farquharson (eds.), Variation in the Caribbean. Amsterdam/Philadelphia: John Benjamins, 39-55. 